\title{
Correction to: First-year university students' academic success: the importance of academic adjustment
}

\author{
Els C. M. van Rooij ${ }^{1}$ - Ellen P. W. A. Jansen ${ }^{1}$ • \\ Wim J. C. M. van de Grift ${ }^{1}$ \\ Published online: 8 January 2018 \\ C The Author(s) 2018. This article is published with open access at Springerlink.com
}

\section{Correction to: Eur J Psychol Educ \\ https://doi.org/10.1007/s10212-017-0347-8}

The article "First-year university students' academic success: the importance of academic adjustment," written by Els C. M. van Rooij, Ellen P. W. A. Jansen, and Wim J. C. M. van de Grift, was originally published electronically on the publisher's internet portal (currently SpringerLink) on 4 November 2017 without open access.

With the author(s)' decision to opt for Open Choice, the copyright of the article changed on 20 December 2017 to (C) The Author(s) 2017 and the article is forthwith distributed under the terms of the Creative Commons Attribution 4.0 International License (http://creativecommons. org/licenses/by/4.0/), which permits use, duplication, adaptation, distribution, and reproduction in any medium or format, as long as you give appropriate credit to the original author(s) and the source, provide a link to the Creative Commons license, and indicate if changes were made.

The original article has been corrected.

Open Access This article is distributed under the terms of the Creative Commons Attribution 4.0 International License (http://creativecommons.org/licenses/by/4.0/), which permits use, duplication, adaptation, distribution, and reproduction in any medium or format, as long as you give appropriate credit to the original author(s) and the source, provide a link to the Creative Commons license, and indicate if changes were made.

The online version of the original article can be found at https://doi.org/10.1007/s10212-017-0347-8.

Els C. M. van Rooij

e.c.m.van.rooij@rug.nl

Ellen P. W. A. Jansen

e.p.w.a.jansen@rug.nl

Wim J. C. M. van de Grift

w.j.c.m.van.de.grift@rug.nl

1 Department of Teacher Education, University of Groningen, Grote Kruisstraat 2/1, 9712

TS Groningen, The Netherlands 